\title{
Clinical and pathological aspects of multicentric hemangiosarcoma in a Pinscher dog
}

\author{
[Sinais neurológicos multifocais devido ao hemangiossarcoma multicêntrico em \\ um cão Pinscher: aspectos clínicos e patológicos]
B.D.C. Martins ${ }^{1}$, B.B.J. Torres ${ }^{1}$, A.A.M. Rodriguez ${ }^{2}$, C.O. Gamba ${ }^{1}$, G.D. Cassali ${ }^{3}$, G.E. Lavalle ${ }^{2}$, G.D.C. Martins ${ }^{4}$, E.G. Melo
${ }^{1}$ Aluno de pós-graduação - Escola de Veterinária - Universidade Federal de Minas Gerais - Belo Horizonte, MG
${ }^{2}$ Médico veterinário - Escola de Veterinária - UFMG - Belo Horizonte, MG
${ }^{3}$ Instituto de Ciências Biológicas - Universidade Federal de Minas Gerais - Belo Horizonte, MG
${ }^{4}$ Médico veterinário residente - Escola de Veterinária - UFMG - Belo Horizonte, MG
${ }^{5}$ Escola de Veterinária - Universidade Federal de Minas Gerais - Belo Horizonte, MG

\begin{abstract}
A 3-year-old female Pinscher dog was presented with a history of lameness and pain in hind limbs for one week which acutely progressed to non-ambulatory paraparesis. The dog had been apathetic and anorexic during the six days prior to presentation. The neurological findings were compatible with upper motor neuron signs to the left hind limb due to a spinal cord compressive mass on the twelfth thoracic vertebral body. On the other hand, signs of lower motor neurons to the right hind limb were due to a mass with a pathological fracture in the right proximal femur, compressing the sciatic nerve. A histopathological analysis of all organs revealed the proliferation of endothelial cells showing infiltrative growth and organization into vascular structures with a solid pattern. In addition, immunohistochemycal analysis revealed low proliferation index and citoplasmatic positivity for CD-31, confirming the vascular nature of the neoplasm. Clinical, histopathological and immunophenotipical findings were consistent with hemangiosarcoma.
\end{abstract}

Keywords: dog, neuropathy, hemangiosarcoma, CD-31, immunohistochemistry

\section{RESUMO}

Uma cadela Pinscher de três anos de idade foi atendida em Hospital Veterinário Escola com histórico de dor nos membros pélvicos com progressão aguda para paraparesia não ambulatória. $O$ animal estava apático e anoréxico há seis dias. Os achados neurológicos foram compatíveis com sinais de lesão de neurônios motores superiores para o membro pélvico esquerdo devido a uma massa no $12^{\circ}$ corpo vertebral comprimindo a medula espinhal. Por outro lado, foram observados sinais de lesão de neurônios motores inferiores para o membro pélvico direito devido a uma fratura patológica no colo proximal do fêmur direito que comprimiu o nervo isquiático. Análises histopatológicas de todos os órgãos revelaram proliferação de células endoteliais com crescimento infiltrativo e organização sólida em estruturas vasculares. Adicionalmente, a análise imuno-histoquímica revelou baixa proliferação e marcação citoplasmática positiva para CD-31, confirmando a natureza vascular da neoplasia. Os achados clínicos, histopatológicos e imuno-histoquímicos foram consistentes com hemangiossarcoma.

Palavras-chave: cão, neuropatia, hemangiossarcoma, CD-31, imuno-histoquímica

\section{INTRODUCTION}

Hemangiosarcoma (HSA) is a highly malignant neoplasm of vascular endothelial origin that

Recebido em 8 de setembro de 2011

Aceito em 28 de agosto de 2012

E-mail: bdcm@vet.grad.ufmg.br occurs more frequently in dogs than in other species and is characterized by high fatality rate. It represents up to $7 \%$ of all tumors and $12 \%$ to $21 \%$ of all mesenchymal neoplasms in dogs (Clifford et al., 2000; Smith, 2003; Schultheiss, 2004; Thamm, 2007). It affects mostly 
middle-aged to older animals and large breed dogs. German shepherds, Golden and Labrador retrievers and Schnauzers are overrepresented in many case series (Smith, 2003; Hidaka et al., 2007; Hristov et al., 2007).

The etiology is unknown, although the strong breed association suggests an inherited or familial predisposition (Clifford et al., 2000). There is increasing evidence that the dysregulation of molecular pathways governing angiogenesis may be important in the pathogenesis of HSA. This suggests the potential for autocrine stimulation of one or more of receptors leading to dysregulated proliferation and survival (Thamm, 2007).

HSA may be solitary, multifocal within an organ, or widely disseminated at presentation (Thamm, 2007). The tumor may arise in any site of the body. However, the most common primary sites in dogs are spleen, skin/subcutis, right atrium and liver (Smith, 2003). Canine HSA is typified by very aggressive biologic behavior with rapid and widespread metastasis being common. Due to its high metastatic capacity, $80 \%$ of patients may have evidence of metastases at the time of initial examination (Smith 2003). The most predisposed tissues to metastasis are the lungs, liver, heart, skin, skeletal muscles, kidney, brain and bones (Gabor et al., 2006; Hidaka et al., 2006).

The complaints presented vary depending on the location of the primary and/or metastatic tumor and can range from nonspecific signs of illness, to specific system involvement or to acute death secondary to hemorrhagic/hypotensive shock (Thamm, 2007; Hammond and Crosby, 2008; Bojrab et al., 2010). The neuropathies due to neoplasm are reported in dogs and clinically defined according to their primary or metastatic site (Bagley, 2010). They can be caused by direct injury, when the tumor is localized in nervous system, or indirectly, when it is localized in a perineural tissue with secondary involvement of neural structures (Luttgen et al., 1980; Lecouteur et al., 2007).

The purpose of this article is to describe the clinical and pathological findings of a 3-year-old Pinscher presented with multifocal neurologic signals due to multicentric HSA.

\section{CASE DESCRIPTION}

A 3-year-old female Pinscher dog, weighting $3 \mathrm{~kg}$, was referred to the Neurological and Neurosurgical Service of Veterinary Teaching Hospital with a history of lameness and pain in hind limbs for one week which acutely progressed to non-ambulatory paraparesis. Forty five days earlier the animal had been submitted to total splenectomy due to hemangiosarcoma. After that, chemotherapy was instituted based on doxorubicin $\left(30 \mathrm{mg} / \mathrm{m}^{2}\right.$, IV) followed by cyclophosphamide $\left(50 \mathrm{mg} / \mathrm{m}^{2}, \mathrm{PO}\right.$, on days 1 and 4 to 7 ). The first protocol would be repeated 21 days later. Upon physical examination, the animal showed apathy, anorexia, weight loss, pale mucous membranes with delayed capillary refill, tachycardia with poor pulse quality and mild hypothermia. On palpation, there were discrete swelling and pain in the left proximal humerus and marked swelling, hardening, pain and creptation in the proximal region of the right femur. Neurologically, the dog had non-ambulatory paraparesis and absence of proprioception in both limbs. In the right pelvic limb flaccid paresis, severe biceps femoris, semitendinosus and semimembranosus atrophy, patellar hyperreflexia and decreased withdrawal reflex were observed. In the left pelvic limb (LPL) spastic paresis, patellar hyperreflexia and normal withdrawal reflex were observed. Decreased superficial pain was observed in both limbs. The evaluation of cranial nerves was unremarkable and, although there was an increased volume in the left proximal humerus, the forelimbs showed no neurological deficits. Upon vertebral spine palpation thoracolumbar hyperesthesia was noted.

Hematological and biochemical profile and left humeral, right femoral and thoracolumbar vertebral spine radiographs were performed. Normocytic normochromic anemia, mild lymphopenia, elevated cholesterol and serum creatine phosphokinase were observed. Radiographs showed a diffuse, mottled, "moth-eaten" appearance of the humerus, with periosteal osteogenesis. Moreover, there were bone lytic changes and intense periosteal proliferation with a suggestive pathological fracture of the right femoral neck (Figure 1). Interestingly, the thoracolumbar spinal radiographs revealed no remarkable findings. Fine needle aspiration biopsy was performed at 
the site, and its smear was chiefly composed of blood components. The owner refused the performance of further tests such as chest radiograph, abdominal ultrasound and echocardiography to search for other metastasis. Given the poor prognosis, the owner opted for euthanasia of the animal. At necropsy, multifocal, variably sized (pinpoint to $2 \mathrm{~cm}$ in diameter), dark red to black nodules, diffused scattered throughout the lungs, kidneys, liver, left occipital lobe cortex, subcutis, stomach and peritoneum were noted. The spinal cord was compressed by a vertebral body mass in the 12 th thoracic vertebra (Figure 2). Additionally, there was a mass in the left humerus and in the right femur which had a fracture and intense bone and fibrous proliferation. This resulted in an inflammatory reaction in the surrounding soft tissue which was compressing the sciatic nerve.

In the histopathological analysis lungs, kidneys, liver, brain, spinal cord and right femur revealed neoplastic masses composed by endothelial cell proliferation forming vascular clafts or channels (Figure 3). Moderate to intense pleomorphism and moderate anisokaryosis were noted, with shape ranging from fusiform to polygonal. The nucleus showed multiple nucleoli. Also, four to six typical and atypical mitoses were observed at 400x magnification.

Immunohistochemical analysis was performed in the spinal cord and right femur neoplastic masses and biotin-peroxidase system was used with the identification of the secondary antibody by the polymer (Advance HRP). The monoclonal antibodies used were Mib-1 (1:25, clone Ki-67) and CD-31 (1:100, clone JC70A). Canine tissue was used as positive control. Negative controls were assessed using normal serum as the primary antibody (Ultra V Block). The proliferative index was calculated by counting the positive nuclei for $\mathrm{Ki}-67$ staining in a total of 500 neoplastic cells from each lesion (Dutra et al., 2008). Qualitative analysis was utilized for CD-31 evaluation.

Immunohistochemistry showed a variable granular cytoplasmatic staining with CD-31 antigen in neoplastic cells, supporting an endothelial origin (Figure 4). The nuclear staining for Ki-67 was $1.6 \%$ for the evaluated neoplastic tissues. The histopathological and immunophenotypical findings were most consistent with hemangiosarcoma.

\section{DISCUSSION}

Hemangiosarcoma occurs most frequently in dogs between nine and 11 years of age and the large breeds are most commonly affected (Brown et al., 1985; Prymach et al., 1988). No sex predilection has been proven, although there is a slight male predisposition in canine HSA reports (Prymach et al., 1988; Clifford et al., 2000; Smith, 2003). Even though this neoplasm has been reported in a West Highland White Terrier and in a Maltese dog (Hidaka et al., 2006), Pinchers are not a noteworthy breed if considering breed incidence of canine HSA and, moreover, the 3-year-old female presented here also does not have the most common epidemiological data.

Grossly and histologically, the nodules analyzed here have the same features aspreviously reported elsewhere (Tucker et al., 2000; Gabor et al., 2006; Hidaka et al., 2006; Dennler et al., 2007). When HSA is suspected, immunohistochemistry for von Willebrand's factor (factor VIII-related antigen) or CD31 can be used to demonstrate endothelial derivation and support the diagnosis. The CD31, an endothelial cell marker, was useful in differentiating HSA from other carcinomas, and confirmed the histopathological diagnosis of hemangiosarcoma.

HSA can be focal, locally invasive, cutaneous or disseminated (Thamm, 2007). When metastases are widespread, the primary tumor site may be difficult to determine, and a multicentric origin is a possibility (Thamm, 2007). In this case report, it was not clear whether there were notable metastasis at the time of splenectomy or not. That is a strong possibility, since its clinical signs of progression were too fast even with chemotherapy in course. It is worth remembering that dogs with gross evidence of metastasis have a grave prognosis and surgery is just palliative. 


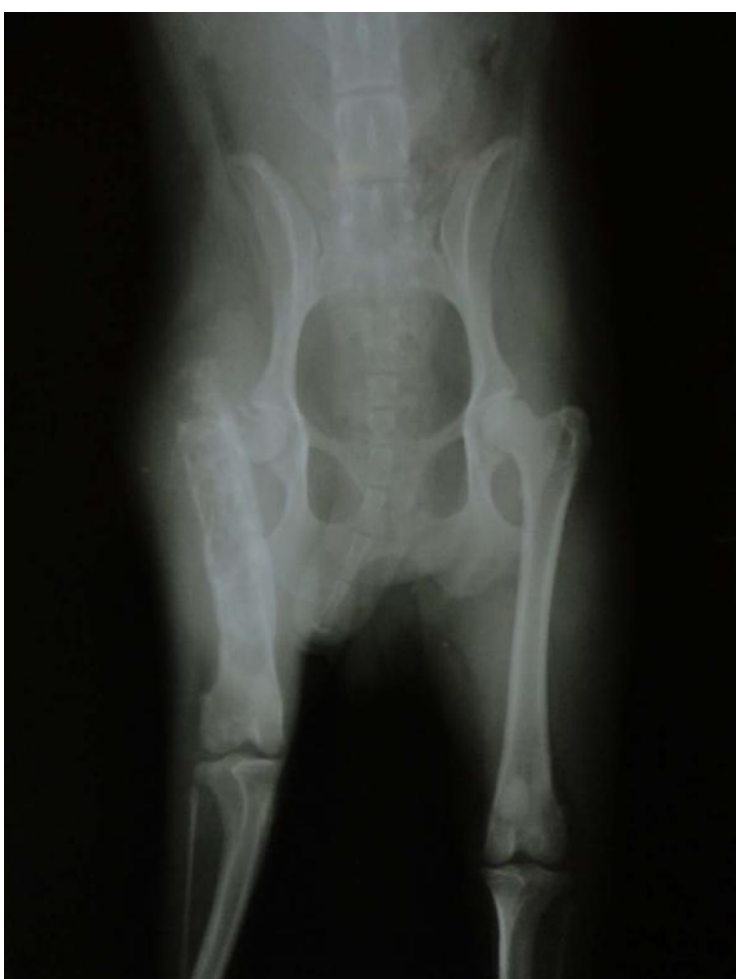

Figure 1. Ventrodorsal radiographic view of the femur of a 3-year-old entire female 294 Pinscher dog with isquiatic neuropathy due to metastatic hemangiosarcoma. Bone lytic 295 chances and intense periosteal proliferation with a suggestive pathological fracture of 296 the right femoral neck is noted.

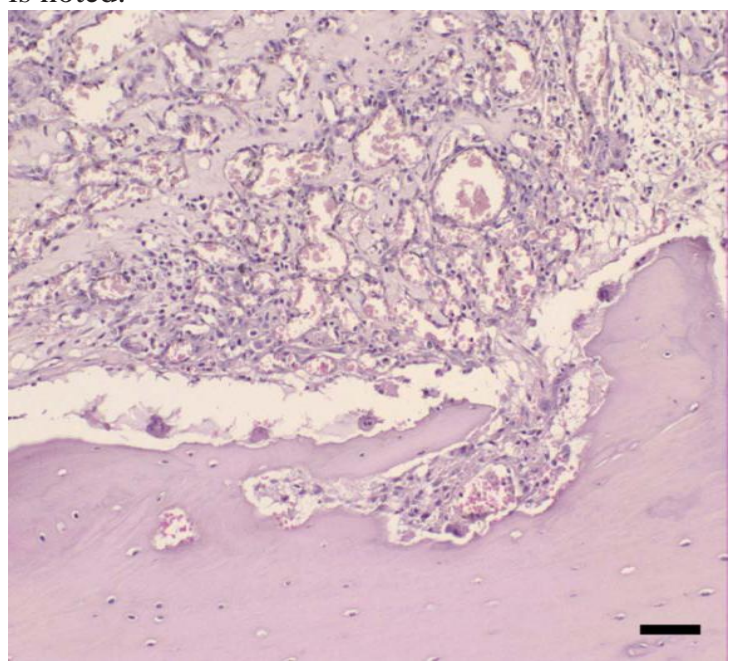

Figure 3. Photomicrograph of hemangiosarcoma of the right femur showing neoplastic 324 cells forming vascular channels and invading the osteous tissue. Canis familiaris. 325 Hematoxilin $\&$ eosin. Bar $=20 \mu \mathrm{m}$.

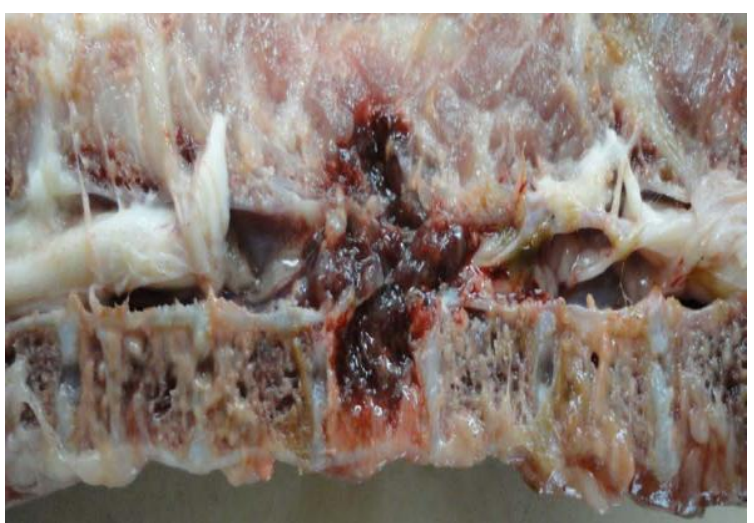

Figure 2. Longitudinal section necroscopy view of the thoracic vertebral spine of a 3-300 year-old entire female Pinscher dog. Compression of the 12th spinal cord segment due to 301 neoplastic mass proliferation is noted.

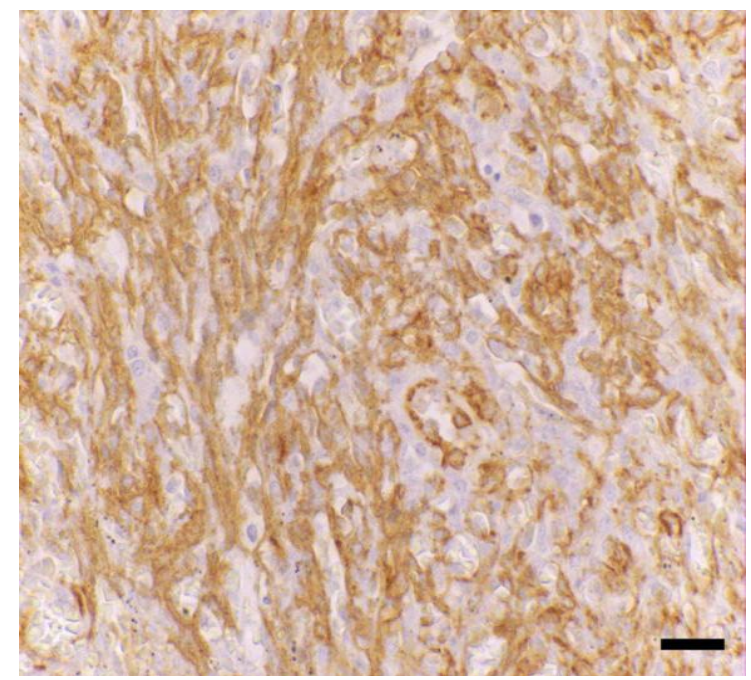

Figure 4. Photomicrograph of hemangiossarcoma of the right femur with variable 340 granular cytoplasmatic staining for CD-31 in endothelial neoplastic cells. Canis 341 familiaris. Bar $=20 \mu \mathrm{m}$. 
HSA is the most prevalent splenic neoplasm and this is the predilection site for primary incidence in dogs (Bojrab et al., 2010). Although the splenectomy can save the dogs life, there is an $80 \%$ of chance that this patient has already had a metastatic lesion at the time of presentation (Smith, 2003). This may occur hematogenously or via local seeding after tumor rupture (Clifford et al., 2000). The average time of survival with a metastatic lesion being detected or not is about four to six months (Bojrab et al., 2010).

Initial presenting signs for HSA are referable to the organ or system involved. If bone and perineural tissue are the sites of primary or metastatic HSA, the presenting signs may include lameness, pain and neurological deficits to the affected limbs (Cuddon et al., 2002; Bagley, 2010).

Primary bone HSA is rare and its incidence is less than $5 \%$ of all primary bone tumors that affect dogs, and the most often affected bones are the humerus, femur, ribs and vertebrae (Hidaka et al., 2006). Clinically, bone neoformation leads to firm swelling and edema of the surrounding tissue. This was observed in the present report, since the vertebral body and the femoral masses were compressing the neurological tissue.

The bones, besides the liver, kidneys, skin, lungs, adrenal glands and brain are more prone to metastasis due to HSA (Smith, 2003). Postmortem examination revealed a nodule in the forebrain that was not associated with any clinical signs. This neoplasm is considered the most common metastatic sarcoma in the brain (Gabor et al., 2006; Lecouteur et al., 2007). In one study of 85 dogs with HSA, 14\% had brain metastasis (Waters et al., 1989).

The spinal cord injury caused by neoplastic mass can result in neurological manifestations that are associated with the affected spinal cord segment (Delahunta, Glass, 2009; Bagley, 2010). A spinal cord injury between the third thoracic and third lumbar spinal cord segments (T3-L3) results in upper motor neuron signs to pelvic limbs. In this report, these signs were observed only in the LPL, due to the vertebral body mass found on the twelfth thoracic vertebra (T12) compressing the spinal cord.
The neurological signs resulting from a spinal cord injury and a peripheral nerve lesion, when presented at the same time, are determined by the most caudal injury (Platt and Olby 2004). As a result, the clinical sign caused by sciatic nerve injury in the right pelvic limb overlaps the one caused by thoracolumbar spinal cord compression leading to lower motor neuron sign. As the LPL did not show peripheral injury, the clinical presentation for this limb was determined by the thoracolumbar spinal cord compression, i.e., upper motor neuron sign.

The sciatic neuropathies may be due to direct or indirect nerve injuries such as pelvic or femoral fracture, neoplasia of bone or soft tissue (Forterre et al., 2007; Delahunta and Glass, 2009). Sciatic nerve injury may cause a flaccid monoparesis, loss of proprioception with weight-bearing maintenance, decreased withdrawal reflex, muscular neurogenic atrophy and loss of the superficial pain perception in the lateral surface of the limb. These findings are consistent with a lower motor neuron injury. In addition, knee flexion, hip extension, tarsus and digits extension and flexion will be compromised (Platt and Olby, 2004; Delahunta and Glass, 2009).

In a clinically similar case report of lower motor neuron lesion a primary hemangiosarcoma of the iliopsoas muscle eliciting a peripheral neuropathy was seen. A mass was identified in the left paralumbar soft tissue adjacent to the fourth (L4) to sixth (L6) lumbar vertebrae leading to a nonweight-bearing lameness in the LPL due to femoral and sciatic nerve roots lesion (Tucker et al., 2000).

Sciatic neuropathies can result in increased patellar reflex (Platt and Olby, 2004). The pseudohyperreflexia presented in this report resulted from decreasing muscle tone responsible for flexing the knee which opposes the extension of this joint during this arch reflex. Moreover, since there was no femoral nerve injury, which is responsible for the innervation of the knee extensor muscles, the patellar reflex was intact.

Surgery still offers the best approach to diagnose and treat HSA even though it is generally only palliative. The effectiveness of adjuvant chemotherapy needs further evaluation (Sorenmo and Jeglum, 1993). New approaches to treatment, such as immunotherapy or 
antiangiogenic therapy, may provide alternatives, and additional investigation into the biology of canine HSA, which researchers hope will lead to clinical trials, is desperately needed (Clifford et al., 2000; Thamm, 2007).

In summary, when affecting nervous system, HSA can cause several neurological signs which would refer to different anatomical levels. These apparently nonspecific signs can confound the vet surgeons and lead them to inaccurate diagnosis. Because of this, the neurological examination should be done very carefully. After examination, the anatomical location of lesions and the differential diagnoses should be discussed in order to administer appropriate treatment.

HSA has a highly aggressive and widespread capacity, regardless of the location of the primary site. Because of this, it should always be treated as systemic disease associating surgery and chemotherapy protocols in order to extend and offer a lifeline to patients with controlled disease.

\section{REFERENCES}

BAGLEY, R.S. Spinal Neoplasms in Small Animals. Vet. Clin. North Am.: Small Anim. Pract., v.40, p.915-927, 2010.

BOJRAB, M.J.; MONNET, E. Mechanisms of disease in small animal surgery. 3. Ed. Teton New Medi, 2010. 788p.

BROWN, N.O.; PATNAIK, A.K.; MAcEWEN, E.G. Canine hemangiosarcoma retrospective analysis of 104 cases. J. Am. Vet. Med. Associat., v.186, p.56-58, 1985.

CLIFFORD, C.A.; MACKIN, A.J.; HENRY, C.J. Treatment of canine hemangiosarcoma: 2000 and beyond. J. Vet. Int. Med., v.14, p.479485, 2000.

CUDDON, P.A. Acquired canine peripheral neuropathies. Vet. Clin. N. Am.: Small Anim. Pract., v.32, p.207-249, 2002.

DELAHUNTA, A.; GLASS, E. Veterinary neuroanatomy and clinical neurology. 3. ed. St Louiz: Saunders, 2009. 540p.
DENNLER, M.; LANGE, E.M.; SCHMIED, O.; KASER-HOTZ, B. Imaging diagnosis Metastatic hemangiosarcoma causing cerebral hemorrhage in a dog. Vet. Radiol. Ultrasound J., v.48, p.138-140, 2007.

DUTRA, A.P.; AZEVEDO JÚNIOR, G.M.; SCHMITT, F.C.; CASSALI, G.D. Assessment of cell proliferation and prognostic factors in canine mammary gland tumors. Arq. Bras. Med. Vet. Zootec., v.60, p.1403-1412, 2008.

FORTERRE, F.; TOMEK, A.; RYTZ, U. et al. Iatrogenic sciatic nerve injury in eighteen dogs and nine cats (1997-2006). Vet. Surgery J., v.36, p.464-471, 2007.

GABOR, L.J.; VANDERSTICHEL, R.V. Primary Cerebral Hemangiosarcoma in a 6Week-Old Dog. Vet. Pathol., v.43, p.782-784, 2006.

HAMMOND, T.N.; CROSBY, A.P. Prevalence of hemangiosarcoma in anemic dogs with a spleen mass and hemoperitoneum requiring a transfusion: 71 cases (2003-2005). J. Am. Vet. Med. Associat., v.232, p.553-558, 2008.

HIDAKA, Y.; HAGIO, M.; UCHIDA, K.; HARA, Y. Primary Hemangiosarcoma of the humerus in a Maltese Dog. J. Vet. Med. Scie., v.68, p.895-898, 2006.

HRISTOV, T.; LAZAROV, L.; SIMEONOV, R.; NIKOLOV, Y. Haemangiosarcoma in a dog. Trakia J. Scie., v.5, p.60-63, 2007.

LECOUTEUR, R.A.; WITHROW, S.J. Tumors of the nervous system. IN: WITHROW, S.J.; MACEWEN, E.G. Small Anim. Clin. Oncol. 4th ed. Philadelphia: WB Saunders Co, 2007. p.659685.

LUTTGEN, P.J; BRAUND, K.G.; BRAWNER, W.R.; VANDEVELDE, M. A retrospective study of twenty-nine spinal tumours in the dog and cat. J. Small Anim. Pract., v.21, p.213226,1980 .

PLATT, S.R.; OLBY, N.J. BSAVA Manual of Canine and Feline Neurology. 3. ed. Athens: BSAVA, 2004. 432p. 
PRYMACH, C.; MCKEE, L.J.; GOLDSCHMIDT, M.H.; GLICKMAN, L.T. Epidemiologic, clinical, pathologic, and prognostic characteristics of splenic hemangiosarcoma and splenic hematoma in dogs: 217 cases (1985). J. Am. Vet. Med. Associat., v.193, p.706-712, 1988.

SMITH, A.N. Hemangiosarcoma in dogs and cats. Vet. Clin. N. Am.: Small Anim. Practs, v.33, p.533-552, 2003.

SORENMO, K.U.; JEGLUM, K.A. Chemotheraphy of canine hemangiosarcoma with doxorubicin and cyclophosphamide. J. Vet. Int. Med., v.7, p.370-376, 1993.

SCHULTHEISS, P.C. A retrospective study of visceral and nonvisceral hemangiomas in domestic animals. J. Vet. Diag. Investigat., v.16, p.522-526, 2004
THAMM, D.H. Miscellaneous tumors: hemangiosarcoma. In: WITHROW, S.J.; MACEWEN, E.G. Small Anim. Clin. Oncology., 4th ed. Philadelphia: WB Saunders Co, 2007. p.785-795.

TUCKER, D.W.; OLSEN, D.; KRAFT, S.L. et al. Primary Hemangiosarcoma of the Iliopsoas Muscle Eliciting a Peripheral Neuropathy. J. Am. Anim. Hosp. Associat., v.36, p.163-167, 2000.

WATERS, D.; HAYDEN, D.; WALTER, P. Intracranial lesions in dogs with hemangiosarcoma. J. Vet. Int. Med., v.3, p.222230, 1989. 